\title{
Modern Approaches for Treatment of Patients with Chronic Wounds in Ambulatory Setting in General Hospital Dr. Jože Potrč Ptuj.
}

\author{
Skender Veliu1, Jasmina Kröpf1², Dominika Vrbnjak ${ }^{3}$
}

\begin{abstract}
Chronic wounds represent an enormous health, social and economic burden in modern society. With the increasing incidence of diabetes and obesity as well as the ageing of the population, we correspondingly expect a rise in the incidence of chronic wounds. The latter will reflect in an even heavier burden for individuals, their families and the society. At the General Hospital Dr. Jože Potrč Ptuj we devote a lot of time dealing with this issue, because we are aware of the impact that the chronic wounds have on the quality of life of affected patients. We have been taking care of patients with chronic wounds for several years in the ambulatory and hospital setting. In the article we present our organizational model in the treatment of patients with chronic wounds at General Hospital Dr. Jože Potrč Ptuj. We present the modern approaches in the treatment of chronic wounds at our hospital, our results in the treatment of chronic wounds supported with clinical cases. The key to successful management of patients with chronic wounds are good knowledge, team work and an individual approach to each patient.
\end{abstract}

Keywords: chronic wounds, wound healing unit, modern approaches, individual approach

${ }^{*}$ Corresponding author: Skender Veliu

$\equiv \triangle$ Email: skender.veliu@gmail.com

1 Surgeon, Surgical Ward, General Hospital Dr. Jože Potrč Ptuj

${ }_{2}^{2}$ Nurse for Controlling Hospital Infection, General Hospital Dr. Jože Potrč Ptuj

${ }^{3}$ Assistant Professor, University of Maribor Faculty of Health Sciences, Slovenia 


\section{Full Text}

\section{Introduction}

Chronic wounds present a challenge to wound care practitioners. Normal wound healing is a complex process that relies on the progression of a series of interdependent phases that repairs tissue damage and, ideally, returns structure and function to the tissue defect. Unlike acute wounds, chronic wounds have impaired healing responses, where they appear to have become stuck in the inflammatory phase of the healing response (1). The healing process can be lengthy, requiring frequent office visits and dressing changes (2).

Wounds are "silent epidemic", having an economic and social impact on our society (3). Evidence suggests that wound care generally, and especially the treatment of chronic wounds, will become a big burden for healthcare systems in Europe as the population ages and because the prevalence of chronic wounds is highly correlated with age (4) .

At the General Hospital Dr. Jože Potrč Ptuj we devote a lot of time dealing treatment of patients with chronic wounds in the ambulatory and hospital setting.

The aim of this article is to present the organizational model in the treatment of patients with chronic wounds at General Hospital Dr. Jože Potrč Ptuj. Modern approaches in the treatment of chronic wounds at hospital, results of the treatment of chronic wounds supported with clinical cases will be presented.

\section{Discussion}

Ambulatory setting for chronic wounds in General Hospital Dr. Jože Potrč Ptuj wound healing unit in hospital started with its activities in June 2015. It operates as a part of specialist surgical unit. Health care team includes; a surgeon, $\mathrm{RN}$ and nursing assistant. The health care team collaborates with community nurses, dietitians, GPs and University Clinical Centre Maribor. Wound healing unit operates twice a week for a full-time. Patients must be appointed to wound healing unit by selected GP. They usually come once or twice a week for examination. Other wound dressings are arranged by community nurses or nurses in primary care. Health care team treats patients with shin ulcers, pressure ulcer, diabetic feet and patients with malignant wounds. During the treatment several parameters are being monitored, such as size of wound (width, length and depth), bottom of the wound, edges of the wound, surrounding skin, secretion (amount and color), possible odor, presence of pain and inflammation. Treatment of each patient is documented with photographs of the wound at the beginning of treatment, wound changes and at the end of treatment. Treatment of the patient includes also dietary counseling and caring for the quality of the patient's life (5).

Modern approaches for chronic wound treatment in ambulatory setting The challenge faced by clinicians is to 'convert' chronic wounds into healing 
wounds by resolving the signals responsible for the delayed healing profile and stimulating/optimizing the healing response (6). Today there are many known methods of treating acute chronic wounds.

The TIME framework provides a systematic approach for the assessment and management of the majority of acute and chronic wounds. The debridement of devitalized tissue from the wound bed, the reduction in wound bioburden and effective management of wound exudate i.e., wound bed preparation are barriers to wound healing progression that are targeted by T.I.M.E (6). The clinical observations and interventions relating to wound bed preparation are grouped into four areas, all of which need to addressed at each wound assessment: Tissue: assessment and debridement of non-viable or foreign material (including host necrotic tissue, adherent dressing material, multiple organism-related biofilm or slough, exudate and debris) on the surface of the wound. Infection/inflammation: assessment of the etiology of each wound, need for topical antiseptic and/or systemic antibiotic use to control infection and management of inappropriate inflammation unrelated to infection. Moisture imbalance: assessment of the etiology and management of wound exudate. Edge of wound: assessment of nonadvancing or undermined wound edges (and state of the surrounding skin). Although there are many new developments in the field of wound therapy and our understanding of wounds, the basic concepts of tissue, infection/inflammation, moisture and edge of wound remain important in guiding clinical practitioners in their approach to wound management (7).

The epithelialization process is impaired in all types of chronic wounds. Problematic are especially wounds that do not epithelize despite the preparation of wound bottom according to TIME (8). In such wounds, other advanced treatment methods need to be considered (5).

Negative pressure wound therapy (NPWT) is being used in hospital since 2009. NPWT is a non-invasive therapy system with controlled negative pressure. It uses a vacuum device to promote wound healing by removing fluid from open wounds through a sealed dressing or a foam dressing connected to a collection container using sub-atmospheric pressure (9). There are several NPWT mechanisms of action: macrodeformation, microdeformation, fluid removal and environmental control of the wound (10). NPWT promotes a moist environment, reduces edema, creates a positive wound environment by removing healing inhibitors, increases blood flow, stimulates angiogenesis and granulation tissue and causes mechanical stress in the bed of the wound promoting cell proliferation (9). The effects of NPWT can deliver different treatment goals: managing and protecting the wound, prepare the wound for surgical closure/to progress the wound by secondary intention, to improve outcomes after split-thickness skin graft, to improve patient comfort and reduce costs (11). Costs are reduced due to faster healing rates and reduced dressing changes; nurse time and hospital stays with NPWT therapy may offset higher acquisition costs (12). There are several 
manufacturers of NPWT devices. The amount of the pressure is determined on the basis of a clinical judgement.A negative pressure of $100-125 \mathrm{~mm} \mathrm{Hg}$ is recommended as the most effective to eliminate the secretion and a pressure of $40-80 \mathrm{~mm} \mathrm{Hg}$ as the most suitable for wound contraction. The recommended pressure for the use of the foam is $125 \mathrm{~mm} \mathrm{Hg}$, and the gauze is $80 \mathrm{~mm} \mathrm{Hg}(13)$.

Bioptron therapy uses a non-invasive optical device to project a beam of light on to the skin. This light has four characteristics, the combination of which is unique to Bioptron: polarisation, polychromy, incoherency, it has low energy density. The manufacturers claim that these characteristics enable Bioptron light to penetrate the skin and underlying tissues in order to stimulate various biological processes. They assert that Bioptron light improves microcirculation, stimulates regeneration and repair, promotes wound healing and relieves pain, with no adverse effects (14). Positive effect of using light therapy is reported in the healing of shin ulcers, burns, skin donor sites and operative wounds (15). They also find effective healing of the diabetic foot using polarized, polychromatic light (16). Use of polarized, polychromatic light reduces the size of pressure ulcers $(17,18)$. Other positive outcomes of using polarized, polychromatic light is also pain reduction $(19,20)$.

In the period from 1. 1. 2016 to 31.12 . 2017 wound healing unit in our hospital completed treatment in 105 patients with various types of chronic wounds. 66 chronic wounds (61\%) were completely healed. We recorded improvement of a local conditions in 29 cases $(27 \%)$ of chronic wound and unchanged local wound state in 12 cases $(11 \%)$. In the two-year period, the average number of treatments needed for total healing of the chronic wound was 12 treatments (3-42), representing an average of 84 days. The average number of light therapies until the first improvement of the wound local status was 2 therapies.76 patients (72\%) reported pain caused by chronic wounding prior treatment and only 26 patients $(25 \%)$ reported pain in association with chronic wound at the last treatment with light therapy (21). Bioptron is being used in hospital as a supportive treatment since November 2015.

Soon after the discovery of lasers in the 1960s it was realized that laser therapy had the potential to improve wound healing and reduce pain, inflammation and swelling (22). Low level laser therapy (LLLT), also called soft laser, is known to supply direct biostimulative light energy to body cells. The absorbed laser energy stimulates molecules and atoms of cells but does not cause rapid or significant increase in tissue temperature (23).

The currently proposed theory regarding the biologic mechanism of LLLT resides in the absorption of light by photo acceptors or chromophores at the molecular, cellular, and tissue levels, that results incellular changes including synthesis of collagen and extracellular matrix, recruitment of cytokines and growth factors, migration, proliferation, and differentiation of cells. LLLT is dependent on the optical absorption 
proper-ties of the skin, frequency of treatment, and treatment intervention time, and is also a function of the device characteristics such as wavelength $(\mathrm{nm})$, power density $(\mathrm{mW} / \mathrm{cm} 2)$, fluence $(\mathrm{J} / \mathrm{cm} 2)$, irradiation time (seconds), and treatment protocol (duration and interval) (24). For wound healing the most appropriate wavelength of laser radiation is in the red spectrum (25). In lasers radiating in the infrared part of the visible spectrum the light penetrates to a depth of $1-2 \mathrm{~cm}$, with indirect effects up to a depth of $5 \mathrm{~cm}$ (26).

For wound radiation the most suitable parameters have not yet been determined (27). In our hospital K Laser is being used. Patients come on therapy twice a week. We use pattern scanning technique, wavelength of 660 nm, $800 \mathrm{~nm}, 905 \mathrm{~nm}, 970 \mathrm{~nm}$ (all for wavelengths work simultaneously), power od $4 \mathrm{~W}-8 \mathrm{~W}$ (constant and pulsating wave) radiation dose of 825 $\mathrm{J}$ for wound area and $2880 \mathrm{~J}$ or $4800 \mathrm{~J}$ for surrounding area (total dose for the entire area), depending on the time radiation (6 or 8 minutes) (28). Effectienes of the treatment is influenced by location and condition of the wound (22). K laser is being used in our hospital since February 2018.

In 2013 an automated epidermal harvesting system (CelluTome Epidermal Harvesting System; KCI, an Acelity company, San Antonio, TX, USA) that applies negative pressure to harvest epidermal microdomes was commercially introduced. The CELLUTOMETM Epidermal Harvesting System is a minimally invasive tool for harvesting epidermal micrografts and is designed for use in the office or outpatient setting. This system combines suction and warmth and produces consistent thin sections of epidermal skin. The technology of the device involves splitting the dermalepidermal junction to form microdomes (ie. blisters), which are harvested into epidermal micrografts. These micrografts consist of undamaged epithelium with keratinocytes (Kci).The system yields up to 128 epidermal micrografts. The system heats the skin to between $37^{\circ} \mathrm{C}$ and $41^{\circ} \mathrm{C}$ and applies $400-500 \mathrm{mmHg}$ of negative pressure.

The microdome preparation takes from 15 to 60 minutes; the preparation is complete when round epidermal microdomes form. The microdomes are secured in place by using compression wrapping, a bolster dressing, or with NPWT. The epidermal grafts can be used on wounds that have a clean granulating base that is free of nonviable tissue(29). This system is also used in General Hospital Dr. Jože Potrč Ptuj, Slovenia, since 2016. Epidermal grafting or using autologous epidermis that has been minced to expand and cover wounds much larger than the donor site, are an alternative to traditional autografts using only a minimal amount of autologous tissue from the donor site $(30,31)$. Only the epidermal portion of the donor area is grafted. This means that the graft acquires the epidermal architecture and characteristics of the recipient site, not the donor site, what potentially leads to better color match and cosmetic outcome $(31,32)$.

Traditional types of autografts include full-thickness and split-thickness skin grafts. Some disadvantages of autografts include the need for a 
surgical procedure with anesthesia, creation of a second wound on donor site, difficulty in obtaining uniform graft thickness, pain, and challenges with graft take and graft rejection (33, 34). Problems with the donor site may include excessive pain, pruritus, infection, dyschromia, delayed healing, and hypertrophic scarring, particularly in patients with poor healing properties due to various comorbidities (35, 36$)$ ). Another drawback to traditional skin grafting techniques is the cosmetic outcome, including hypopigmentation, hyperpigmentation, and hypertrophic scarring (37).

Endovenous laser ablation (EVLA) is a commonly used and very effective minimally invasive therapy to manage leg varicosities (38). Clinically, scientifically, and commercially, it is a fascinating therapy. Clinically, because EVLA took over surgical stripping as a result of its very high success rate with minimal complications at all laser wavelengths, laser powers, and pullback velocities used (39). Scientifically, because the consented mechanism of action, i.e., achieving irreversible thermal injury of the vein wall, may be reached by several mechanisms of which the individual contribution is still under debate (40, 41). Commercially, because gaps in knowledge of the mechanism of action created space for a wide variety of treatment protocols, frequently introduced as new and more effective laser wavelengths (42).

There are two main modes of action in EVLA proposed so far, both related to the conversion of absorbed laser light energy into heat. The first is heating of blood, vein wall, and perivenous tissue by direct absorption of the laser power emitted from the fiber and scattered by the blood towards the other tissues, where the generated heat in the blood also diffuses to the vein wall (43-45). The second mode of action is heating of the vein wall by heat transfer from the hot black layer of carbonized blood sticking to the fiber tip. This transfer may be via direct contact between the hot tip and the vein wall $(42,46)$, via diffusion through the blood $(43,47)$, by boiling steam bubbles which are formed in the hot carbonized layer, grow, detach, and travel downstream from the tip to condense near or at the wall $(48,49)$, or by Planck's black body radiation (45).

Ecchymoses and pain are frequently reported side effects of endovenous laser ablation. Nerve injury, skin burns, deep vein thrombosis and pulmonary embolism seldom occur. An exceptional complication is a material or device that by accident remains inside the body after the procedure. Ecchymosis, pain, induration, skin burns, dysesthesia, superficial thrombophlebitis, and hematoma were classified as minor complications. Deep vein thrombosis and nerve injury were classified as major complications. Endovenous laser ablation may be considered a safe treatment of lower extremity varicosities. The incidence of common side effects may decrease with better laser parameter (50).EVLA operations are carried out from 2016 and we perform 75 operations annually.

\section{Conclusions}


Chronic wounds are a complex problem as they affect all areas of human life and activity. The goal of treating patients with chronic wounds in our wound healing unit is not only the healing of a chronic wound, but the overall rehabilitation of the patient. To achieve the goal, good professional knowledge, teamwork and, above all, individual and integrated treatment of each individual patient is indispensable.

\section{References}

1. Enoch S, Harding K. Exudate levels in chronic wounds. Wounds. 2003;15(7):213.

2. Serena TE. Use of epidermal grafts in wounds: a review of an automated epidermal harvesting system. Journal of Wound Care. 2015;24(4 Suppl):30-4.

3. Sen CK, Gordillo GM, Roy S, Kirsner R, Lambert L, Hunt TK, et al. Human Skin Wounds: A major and snowballing threat to public health and the economy. Wound Repair and Regeneration. 2009; 17(6):763-71.

4. Posnett J, Gottrup F, Lundgren H, Saal G. The resource impact of wounds on health-care providers in Europe. Journal of Wound Care. 2009;18(4):154-61.

5. Veliu S, Vrbnjak D, Kröpfl J. Izkušnje $\mathrm{z}$ uporabo svetlobne terapije pri zdravljenju kroničnih ran. In: Smrke D, Nikolič J. eds. Rana - včeraj, danes, jutri? Simpozij o ranah: zbornik predavanj, 2017, april 19-21, Portorož, Slovenija. Ljubljana: Klinični oddelek za kirurške okužbe, Kirurška klinika,
Univerzitetni klinični center. 2017;65-67.

6. Ousey K, Rogers AA, Rippon MG. Hydro-responsive wound dressings simplify TIME wound management framework. British Journal of Community Nursing. 2016;21(112 Suppl):39-9.

7. Leaper DJ, Schultz G, Carville K, Fletcher J, Swanson T, Drake R. Extending the TIME concept: what have we learned in the past 10 years? International Wound Journal. 2012;9(2):1-19.

8. Pastar I, Stojadinovic O, Yin NC, Ramirez H, Nusbaum AG, Sawaya A, et al. Epithelialization in wound healing: a comprehensive review. Advances in Wound Care (New Rochelle). 2014;3(7): 445-64.

9. Meloni M, Izzo V, Vainieri $\mathrm{E}$, Giurato L, Ruotolo V, Uccioli L. Management of negative pressure wound therapy in the treatment of diabetic foot ulcers. World Journal of Orthopedics. 2015; 6(4):387-93.

10. Orgill DP, Bayer LR. Negative pressure wound therapy: past, present and future. International Wound Journal. 2013;10 (Suppl 1):15-9.

11. Birke-Sorensen $H$, Malmsjo $M$, Rome P, Hudson D, Krug E, Berg L, et al. Evidence-based recommendations for negative pressure wound therapy: treatment variables (pressure levels, wound filler and contact layer)--steps towards an international consensus. Journal of Plastic, Reconstructive \& Aesthetic Surgery. 2011;64 Suppl:116.

12. European Wound Managemet Association. 2007. Topical negative pressure in wound management. Position Document. Available at: 
http://www.woundsinternational. com/media/issues/84/files/conte nt_46.pdf

13. Laginja S, Marinović M. Primjena terapije negativnim tlakom. Acta Medica Croatica. 2016;70 (Supl 1):97-100.

14. Bowens A. Evidence based review: Bioptron light therapy. Available at:

http://www.sensolite.com/eviden ciapdf/30.pdf

15. Hawkins D, Abrahamse H. 2007. Phototherapy - a treatment modality for wound healing and pain relief. African Journal of Biomedical Research. 2007;1:99-109.

16. El-Deen HB, Fahmy S, Ali SA, ElSayed WM. 2014. Polarized light versus light-emitting diode on healing of chronic diabetic foot ulcer. Romanian Journal of Biophysics.2014;24(2):1-15.

17. Iordanou $P, \quad$ Baltopoulos G, Giannakopoulou M, Bellou P, Ktenas E. 2002. Effect of polarized light in the healing process of pressure ulcers. International Journal of Nursing Practice. 2002;8(1): 49-55.

18. Đurović A, Marić D, Brdareski Z, Jevtić $M$, Đurđević $S$. The effects of polarized light therapy in pressure ulcer healing. Vojnosanitetski pregled. 2008;65(12):906-12.

19. Colić MM, Vidojković N, Jovanović M, Lazović G. The use of polarized light in aesthetic surgery. Aesthtic Plastic Surgergy. 2004;28:324-27.

20. Stasinopoulos D, Stasinopoulos I, Johnson MI. Treatment of carpal tunnel syndrome with polarized polychromatic noncoherent light (Bioptron light): A preliminary, prospective, open clinical trial.
Photomededicine and Laser Surgery. 2005;23(2):225-8.

21. Veliu S, Kröpfl J, Vrbnjak D. Vpliv polarizirane, polikromatske svetlobe na celjenje ran. In: Frangež I, Nikolič J (eds). Kirurški in/ali konzercativni pristop $\mathrm{k}$ zdravljenju kronične rane?, 13. simpozij o ranah z mednarodno udeležbo, 19. do 20. april 2018 Portorož, Slovenija. Ljubljana: Klinični oddelek za kirurške okužbe, Kirurška klinika, Univerzitetni klinični center. 2018: 114-118.

22. Chung H, Dai T, Sharma SK, Huang YY, Carroll JD, Hamblin MR. The nuts and bolts of low-level laser (light) therapy. Annals of Biomedical Engineering. 2012; 40(2):516-33.

23. Saltmarche AE. Low level laser therapy for healing acute and chronic wounds - the Extendicare experience. International Wound Jorunal. 2008;5(2):351-60.

24. Prindeze NJ, Moffatt LT, Shupp JW. Mechanisms of action for light therapy: a review of molecular interactions. Experimental Biology and Medicine (Maywood). 2012;237:1241-8.

25. Moore KC, Calderhead RG. The clinical application of low incident power density $830 \mathrm{~nm}$ GaAlAs diode laser radiation in the therapy of chronic intractable pain: a historical and optoelectronic rationale and clinical review. International Journal of Optoelectronics.1991;6(5):503-20.

26. Marolt M, Kos N, Sedej B. Uporaba nizkoenergijskega laserja $\mathrm{v}$ fizikalni medicini in rehabilitaciji - naše izkušnje. In: Frangež I, Ban Frangež $\mathrm{H}$ (eds). Svetlobna terapija v medicini - fotobiomodulacija. 1. 
simpozij združenja za fotomedicino in fotobiologijo, 2012, oktober 20, Ljubljana, Slovenija. Ljubljana: Slovensko združenje za fotomedicino in fotobiologijo. 2015: 75-8.

27. Da Silva JP, da Silva MA, Almeida, AP, Lombardi Junior I, Matos AP. Laser therapy in the tissue repair process: a literature review. Photomedicine and Laser Surgery. 2010;28(1):17-21.

28. Veliu S, Kröpfl J, Vrbnjak D.Obravnava bolnikov $\mathrm{s}$ kroničnimi ranami v Splošni bolnišnici dr. Jožeta Potrča Ptuj. In: Frangež I, Nikolič J (eds). Kirurški in/ali konzercativni pristop $\mathrm{k}$ zdravljenju kronične rane?, 13. simpozij o ranah $\mathrm{z}$ mednarodno udeležbo, 19. do 20. april 2018 Portorož, Slovenija. Ljubljana: Klinični oddelek za kirurške okužbe, Kirurška klinika, Univerzitetni klinični center. 2018: 126-31.

29. Serena TE. Use of epidermal grafts in wounds: a review of an automated epidermal harvesting system. Journal of Wound Care. 2015;24(4 Suppl):30-4.

30. Biswas A, Bharara M, Hurst C, Armstrong DG, Rilo $H$. The micrograft concept for wound healing: strategies and applications. Journal of Diabetes Science and Technology. 2010;4(4):808-19.

31. Osborne SN, Schmidt MA, Harper JR. An automated and minimally invasive tool for generating autologous viable epidermal micrografts. Advances in Skin \& Wound Care. 2016;29(2):57-64.

32. Yamaguchi $Y$, Itami S, Tarutani $M$, Hosokawa K, Miura H, Yoshikawa K. Regulation of keratin 9 in nonpalmoplantar keratinocytes by palmoplantar fibroblasts through epithelial-mesenchymal

interactions. Journal of

Investigative

Dermatology1999;112(4):483-8.

33. Kim PD, Fleck T, Heffelfinger R, Blackwell KE. Avoiding secondary skin graft donor site morbidity in the fibula free flap harvest. Archives of Otolaryngology--Head \& Neck Surgery. 2008;134(12):13247.

34. Shindo M, Fong BP, Funk GF, Karnell LH. The fibula osteocutaneous flap in head and neck reconstruction: a critical evaluation of donor site morbidity. Archives of Otolaryngology--Head \& Neck Surgery. 2000;126(12):146772.

35. Chuenkongkaew T. Modification of split-thickness skin graft: cosmetic donor site and better recipient site. Annals of Plastic Surgery. 2003;50(2):212-4.

36. Edwards J. Management of skin grafts and donor sites. Nursing Times. 2007;103(43):52-3.

37. Simizu R, Kishi K, Okabe K, Uchikawa Y, Sakamoto Y, Hattori $\mathrm{N}$, et al. Recruited minced skin grafting for improving the skin appearance of the donor site of a split-thickness skin graft. Dermatologic Surgery. 2012;38(4):654-60.

38. Malskat WS, Poluektova AA, van der Geld CW, Neumann HM, Weiss RA, Bruijninckx CM, van Gemert, MJ. Endovenous laser ablation (EVLA): a review of mechanisms, modeling outcomes, and issues for debate. Lasers in Medical Science. 2014;29(2):393-403. 
39. van den Bos R, Arends L, Kockaert M, Neumann M, Nijsten T. Endovenous therapies of lower extremity varicosities: a metaanalysis. Journal of Vascular Surgery. 2009;49:230-39.

40. Vuylsteke ME, Mordon SR Endovenous laser ablation: a review of mechanisms of action. Annals of Vascular Surgery. 2012;26(3): 424-33.

41. van Gemert MJ, van der Geld CW, Bruijninckx CM, Verdaasdonk R M, Neumann H. M. Comment to Vuylsteke ME and Mordon SR. Endovenous laser ablation: a review of mechanisms of action. Annals of Vascular Surgery. 2012;26:424-33. Annals of Vascular Surgery. 2012;26(6):881-3.

42. Navarro L, Navarro N, Salat CB, Gomez JF, Min RJ. U.S. Patent No. 6,398,777. Washington, DC: U.S. 2002. Patent and Trademark Office.

43. Mordon SR, Wassmer B, Zemmouri J. Mathematical modeling of 980$\mathrm{nm}$ and 1320-nm endovenous laser treatment. Lasers and Surgery and Medicine. 2007;39:256-65.

44. Mordon, S. R., Wassmer, B., \& Zemmouri, J. Mathematical modeling of endovenous laser treatment (ELT). BioMedical Engineering OnLine. 2006;5(1):26.

45. van Ruijven PW, Poluektova AA, van Gemert MJ, Neumann HM, Nijsten, T, van der Geld CW. Optical-thermal mathematical model for endovenous laser ablation of varicose veins. Lasers in Medical Science.2014;29(2): 431-9.

46. Fan CM, Anderson RR. Endovenous laser ablation: mechanism of action. Phlebology. 2008;23:206-13.

47. van den Bos RR, Kockaert MA, Neumann HM, Bremmer RH, Nijsten T, van Gemert M J. Heat conduction from the exceedingly hot fiber tip contributes to the endovenous laser ablation of varicose veins. Lasers in Medical Science,.2009;24(2):247251.

48. Proebstle TM, Lehr HA, Kargl A, Espinola-Klein C, Rother W, Bethge $\mathrm{S}$, et al. Endovenous treatment of the greater saphenous vein with a 940-nm diode laser: thrombotic occlusion after endoluminal thermal damage by laser-generated steam bubbles. Journal of Vascular Surgery. 2002;35:729-36.

49. van der Geld CWM, van den Bos RR, van Ruijven PWM, Nijsten T, Neumann HAM, van Gemert MJC. The heat-pipe resembling action of boiling bubbles in endovenous laser ablation. Lasers in Medical Science. 2010;25:907-9.

50. Van Den Bos RR, Neumann M, de Roos KP, Nijsten T. Endovenous laser ablation-induced complications: review of the literature and new cases. Dermatologic Surgery. 2009;35(8):1206-14. 